\title{
The effectiveness of biopolymers application for cryopreservation of the fragments of convoluted seminiferous tubules of prepubertal rat's testis
}

Volkova N. O., Yukhta M. S., Chernyschenko L. G., Stepaniuk L. V., Sokil L. V., Goltsev A. M.

Institute for Problems of Cryobiology and Cryomedicine of the National Academy of Sciences of Ukraine, Kharkiv, Ukraine

e-mail:volkovana781@gmail.com

\section{ABSTRACT}

Today, transplantation of cryopreserved fragments of immature testis is a non-alternative method of preserving the fertility of pre-adolescent patients who undergo cytotoxic therapy.

The PURPOSE of the study is to compare the effectiveness of the use of biopolymers (bovine serum albumin and fibrin gel) as the bases of cryoprotective media at low temperature preservation of the fragments of the convoluted seminiferous tubules of prepubertal rats' testis.

MATERIALS AND METHODS. Convoluted seminiferous tubules of prepubertal rats' testis (75 $\pm 3 \mathrm{mg}$ and 6-8 $\mathrm{mm}^{3}$ ), after a 30-minute exposure at $4^{\circ} \mathrm{C}$ in cryoprotective media based on Hanks' solution with $50 \mathrm{~g} / \mathrm{L}$ of bovine serum albumin (BSA) or fibrin gel (FG) supplemented with $0.6 \mathrm{M} \mathrm{DMSO}$ or $0.7 \mathrm{M}$ glycerol, were cryopreserved according to the program: $1^{\circ} \mathrm{C} / \mathrm{min}$ to $-8^{\circ} \mathrm{C}$; stop for 10 minutes; $10^{\circ} \mathrm{C} / \mathrm{min}$ to $-70^{\circ} \mathrm{C}$; stored in liquid nitrogen. After thawing, the histological structure was evaluated and the metabolic activity of the spermatogenic epithelium cells was determined.

RESULTS. According to the results of the histological study, there was a positive tendency of FG application, which had the maximum expressiveness in combination with 0,7 M glycerol. In this case, $68.8 \pm 15.7 \%$ of cell nuclei remained morphologically intact, and changes in the spermatogenic epithelium were slightly pronounced. The metabolic activity of the rats' seminiferous convoluted tubules cells after freezing and thawing remained at a significantly higher level when using FG in combination with $0.6 \mathrm{M}$ DMSO than with $0.7 \mathrm{M}$ glycerol compared to the corresponding cryoprotectant based on the Hanks' solution with BSA.

CONCLUSIONS. The use of fibrin gel in the protocols of cryopreservation promote preservation of the histological structure and metabolic activity of the spermatogenic epithelium.

KEY WORDS: testicular tissue; prepubertal age; dimethyl sulfoxide; glycerol; cryopreservation; bovine serum albumin; fibrin gel

Today, in the field of reproductive biotechnology, the transplantation of cryopreserved fragments of immature testis to restore fertility is actively developing [1]. The advantage of this method is to preserve the compartment of the spermatogenic cells, due to the support of cellular contacts and interaction, which contributes to the normal development of the germ cells. Studies on animal models showed the possibility of restoring complete spermatogenesis after orthotopic and heterotopic transplantation of cryopreserved fragments of immature testicular tissue [2-4]. Healthy progeny was also obtained by intracytoplasmic sperm injection (ICSI) isolated from transplants of cryopreserved testicular tissue of mice and rabbits $[5,6]$. Clinical studies in this direction have not been carried out so far, and modern knowledge on spermatogenesis 
in transplants of cryopreserved human immature testicular tissue is based only on experiments in the xenogeneic system [7-10], in which the differentiation of spermatocytes was observed until the stage of pachynema [9] and the formation of spermatid-like structures [10]. However, today, this approach is quite successful in maintaining fertility in adolescents with non-obstructive azoospermia and Klinefelter syndrome, in which the testicular tissue nevertheless contains at least isolated, but mature sperm, which can be used in the ICSI procedure [11, 12].

The success of experimental transplantation encourages some optimism about the future use of this approach to maintain the fertility of prepubertal patients who undergo cytotoxic therapy. That is why the appropriateness of implementing cryobanking of immature testicular tissue in applied medicine leaves no doubt today.

Existing protocols for cryopreservation of immature testicular tissues of humans and mammals with the use of programmed freezing and multicomponent cryoprotective media $[8,13]$ consist of $3-4$ stages and are based on the use of slow cooling rates $\left(0.5-1^{\circ} \mathrm{C} / \mathrm{min}\right)$ to the crystallization temperature, presence/absence of seeding, subsequent increase of the speed to $10-20^{\circ} \mathrm{C} / \mathrm{min}$ and transfer of the samples in liquid nitrogen at temperatures reaching $-70 \ldots-80^{\circ} \mathrm{C}[14,15]$. Cryoprotectant dimethyl sulfoxide (DMSO) due to low molecular weight and high penetrating ability exceeds ethylene glycol, propandiol and glycerol in minimizing the cryodamage of testicular tissue [16], while retaining the ability to initiate spermatogenesis [17]. Animal studies emphasized the key role of the initial state of spermatogenic cells in the effectiveness of fertility recovery procedures. Comparative studies on the use of fresh and cryopreserved specimens indicate the loss of spermatogonial stem cells during cryopreservation. Thus, the effectiveness of cryopreservation procedures is critical and should be improved [18].

The presence of an extracellular matrix can affect the structure of ice formed during the cooling stages, and the final result of tissue cryopreservation. Therefore, the use of biopolymer gels as matrices for seminiferous convoluted tubules can allow, by reducing the volume of free water, to minimize tissue damage during cryopreservation and preserve its architectonic and morphological and functional structure [19, 20]. However, today the methods of cryopreservation using biopolymers have not reached wide application in reproductive technologies yet.

Our previous studies have shown that the use of biopolymers at the exposure stage reduced the toxic effect of DMSO and glycerol on spermatogenic epithelial cells of prepubertal rats' testis and increased the exposure time [21, 22].

The PURPOSE of the study is to carry out a comparative evaluation of the effectiveness of the biopolymers bovine serum albumin (BSA) and fibrin gel (FG) application as the component of cryoprotective media at low temperature preservation of fragments of seminiferous convoluted tubules of prepubertal rat's testis.

\section{MATERIALS AND METHODS}

The study was performed on prepubertal (7-8 weeks) male rats $(n=50)$ weighing $50 \pm 15 \mathrm{~g}$ [23]. All manipulations with animals were conducted in accordance with international bioethical norms, legislative documents of Ukraine, materials of the IV European Convention for the Protection of Vertebrate Animals used for experimental and other scientific purposes [24] and the protocol of the Committee on Bioethics on the work with experimental animals of the Institute of Problems of Cryobiology and Cryomedicine of the National Academy of Sciences of Ukraine (No. 2014-02).

Seminiferous tubules were obtained mechanically from both testis of rats after euthanasia with $\mathrm{CO}_{2}$. Fragments $\left(75 \pm 3 \mathrm{mg}\right.$ and $\left.6-8 \mathrm{~mm}^{3}\right)$ were cut from the obtained tissue using forceps and scissors for further research. Cryoprotective media were made ex tempore based on:

1. Hanks' solution (PAA, Austria);

2. Bovine serum albumin (PAA, Austria), which was used at a concentration of $50 \mathrm{~g} / \mathrm{L}$ in the Hanks' solution;
3. Fibrin gel, which was obtained from fresh blood of 7-8 weeks-old male rats. The blood in volume 5-7 mL was collected from the cardiac vein, and centrifuged for 15 minutes at $1500 \mathrm{xg}$. After centrifugation, three fractions of blood were obtained: lower - red blood cells, upper - plateletpoor plasma, medium - platelet-rich fibrin gel. Blood samples with hemolysis were not used in the experiment.

The basis component was added with the DMSO cryoprotectant (PanEco, Russia) or glycerol (Dow Chemical, Germany) at a final concentration of $0.6 \mathrm{M}$ and $0.7 \mathrm{M}$, respectively. The tissue fragments were transferred into 2-mL cryovials (Nunc, USA). The exposure of the rats' seminiferous tubules to the media was 30 minutes at $4{ }^{\circ} \mathrm{C}[21,22]$. Cryopreservation was carried out using a freezer ZP-10 according to the program: cooling from $20^{\circ} \mathrm{C}$ to $-8^{\circ} \mathrm{C}$ at a rate of $1^{\circ} \mathrm{C} / \mathrm{min}$; stop for $10 \mathrm{~min}$ utes at $-8^{\circ} \mathrm{C}$; cooling to $-70^{\circ} \mathrm{C}$ at a rate of $10^{\circ} \mathrm{C} / \mathrm{min}$; transferring to liquid nitrogen $\left(-196^{\circ} \mathrm{C}\right)$. The samples were stored in a cryobank for a month. Cryovials were thawed in a water bath at $40{ }^{\circ} \mathrm{C}$ until a liquid phase. Removal of cryoprotectants from the samples was carried out by a threefold wash of the cryopreservation medium to Hanks' solution. Control groups were intact freshly isolated fragments of rats' seminiferous tubules and samples cryopreserved without the use of DMSO or glycerol, respectively.

The samples for histological examination were fixed in $10 \%$ formalin solution, dehydrated, degreased with acetone and ethanol of increasing concentrations and then embedded in paraffin. Obtained 7- $\mu \mathrm{m}$-thick histologic sections, stained with hematoxylin and eosin, and studied using a LSM 510 Meta microscope (Carl Zeiss, Germany). The following basic histological parameters of the spermatogenic epithelium were estimated (Table 1) [25, 26].

The minimum total number of points (0-1 points) corresponded to the intact structure of the spermatogenic epithelium, 1-3 points was considered as weak changes, 3-6 points - moderate changes and more than 6 points - pronounced damage to the spermatogenic epithelium.

Metabolic activity was investigated using the MTT test [27]. For this, samples of rats' seminiferous tubules after cryopreservation were transferred into $1 \mathrm{~mL}$ Hanks' medium, which was added with $0.5 \mathrm{ml}$ MTT solution at a concentration of $5 \mathrm{mg} / \mathrm{mL}$. After 3 hours of incubation (5\% $\mathrm{CO}_{2}, 37^{\circ} \mathrm{C}$ ), the medium was completely removed and the formazan was dissolved by addition of DMSO ( $1 \mathrm{~mL} / \mathrm{sample})$, followed by centrifugation for 10 minutes at $840 \mathrm{xg}$. The optical density of the formazan solution in the supernatant was measured at $540 \mathrm{~nm}$ wavelength.

Cell viability in samples of rats' seminiferous tubules was determined by supravital staining with Trypan Blue. Cell suspension was obtained

Table 1. Histological parameters of the spermatogenic epithelium.

\begin{tabular}{|c|c|c|}
\hline PARAMETER & GRADE & POINTS \\
\hline \multirow{3}{*}{ CELLS RETRACTION } & absent & 0 \\
\hline & insignificant & 1 \\
\hline & expressed & 2 \\
\hline \multirow{3}{*}{$\begin{array}{l}\text { DESQUAMATION OF CELLS } \\
\text { IN THE TUBULAR LUMEN }\end{array}$} & absent & 0 \\
\hline & partial & 1 \\
\hline & $>70 \%$ or total & 2 \\
\hline \multirow{3}{*}{$\begin{array}{l}\text { THE PERCENTAGE OF CELLS WITH } \\
\text { NUCLEAR CONDENSATION }\end{array}$} & absent & 0 \\
\hline & $<40 \%$ & 1 \\
\hline & $>40 \%$ & 2 \\
\hline \multirow{3}{*}{ DEFECTS OF TISSUE } & absent & 0 \\
\hline & single & 1 \\
\hline & diffuse & 2 \\
\hline
\end{tabular}


by enzymatic disaggregation [28]. The percentage of viable cells was determined as the percentage of cells resistant to staining and the total number of cells.

The normality of the distribution was determined by the skewness and the kurtosis. In the normal distribution of variables, the significance of differences between groups was estimated using Student's t-test and presented as $M \pm m$. The critical value of the significance level was assumed to be $p=0.05$. Data analysis was performed using Microsoft Excel (Microsoft, USA) and Statistika 8 (StatSoft Inc., USA) software.

\section{RESULTS AND DISCUSSION}

The results of the histological studies showed that the seminiferous tubule sections of the intact rat had normal structural organization (Fig. 1). Within the seminiferous tubules on the basement membrane, there was a spermatogenic epithelium in several layers, whose germ cells were at different development stages. In the external basal layer, spermatogonia, rounded cells with a hyperchromic nucleus and a thin rim of the cytoplasm, were visualized. Spermatocytes, cells with a large core and a wide border of the cytoplasm, were located in several rows in the inner adluminal layer. In some tubules near the center, there were small round shape cells with a bright nucleus - early spermatids, and, in some cases, elongated cells - late spermatids.

Spermatogenic epithelium after cryopreservation with DMSO was characterized by a pronounced retraction of cells with the formation of fissures and cavities within the spermatogenic layer. The desquamation of the spermatogenic epithelium from the tubular membrane, sometimes totally, was observed. At the same time, the membrane was edematous and thickened. Its contour was unequal. In the epithelial layer, there were defects of round shape with clear even contours. More than $61 \%$ of cells have been pathologically altered, primarily due to nucleus pyknosis (Table 2).

According to the semi-quantitative evaluation, histological structural alterations in the spermatogenic epithelium after cryopreservation with DMSO corresponded to moderately pronounced (Table $\mathbf{3}$ ).

With the use of glycerol without biopolymers, a pronounced retraction of spermatogenic epithelial cells with desquamation occurred similar to DMSO, although the latter was rarely total. The nuclei of most germ cells had hyperchromic, and sometimes foci of lysed cells were detected (Table 2). Therefore, the damage of spermatogenic epithelium in this group remained at the level of moderately pronounced changes (Table 3 ).

In groups with the use of DMSO + BSA and DMSO + FG (Fig. 2, A, B), there was a decrease of the retraction and desquamation of spermatogenic epithelial cells compared to control (DMSO). However, in the first case (DMSO + BSA), the relative number of cells with damaged nucleus remained high, and the pyknotic type predominated among the lesions (Table 2). In comparison with this, the use of DMSO with FG contributed to a relative decrease in the number of cells with the lysis of nuclei. Complex semi-quantitative assessment revealed that programmed

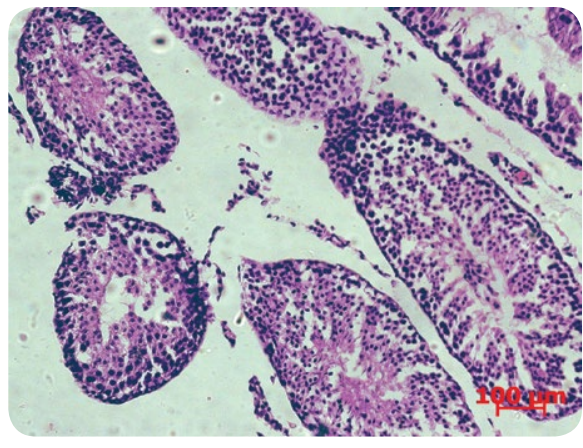

Fig. 1. Microphotography of histological sections of intact convoluted seminiferous tubules of prepubertal rats' testis; hematoxylin and eosin staining.

Table 3. Semi-quantitative evaluation of spermatogenic epithelium alterations, average total score.

\begin{tabular}{|c|c|c|}
\hline GROUP & DMSO & GLYCEROL \\
\hline CONTROL & $5.8(5-7)$ & $3.9(3-5)$ \\
\hline BSA & $5.4(5-7)$ & $2.8(2-4)$ \\
\hline FG & $4.9(4-6)$ & $1.4(1-3)$ \\
\hline INTACT CONTROL & \multicolumn{2}{|c|}{$0.4(0-1)$} \\
\hline
\end{tabular}

Note: the boundary values of the total points in the corresponding group are specified in parentheses.

cryopreservation of convoluted seminiferous tubules of rats' testis using DMSO combined with both BSA and FG caused moderate morphological changes in the spermatogenic epithelium (Table 3).

In experimental groups with using glycerol (glycerol + BSA and glycerol $+F G$ ), the retraction and desquamation of epithelial cells, as well as spherical cavities in the spermatogenic layer, were absent in most sections. It should be noted that alteration of cell nuclei were observed to a lesser extent when using $F G$ as the basis of cryoprotective medium than when using BSA (Table 2). This led to a decrease in the degree of cryoinjury of the spermatogenic epithelium in this group (glycerol $+F G$ ) to 1.4 points (Table 3 ), which corresponds to weak changes.

The analysis of the results of histomorphometric study shows that the use of FG had the positive tendency for cryopreservation of the convoluted seminiferous tubules of prepubertal rats' testis, which had the most pronounced effect in combination with glycerol.

The results of the study of the cryopreservation effects on the metabolic activity of the tissues of the convoluted seminiferous tubules of rats' testis are shown in Fig. 3. Metabolic activity was 1.4 times higher in the samples cryopreserved with DMSO+BSA, than in the corresponding control. The combination of DMSO with FG provided an increase of the investigated index by 2.5 times relative to the corresponding control. The result of the MTT test in samples cryopreserved using glycerol with BSA and FG

\begin{tabular}{|c|c|c|c|c|}
\hline & INTACT & PYKNOTIC & FRAGMENTED & LYZED \\
\hline DMSO & $38.8 \pm 6.7^{1}$ & $35.3 \pm 5.4^{1}$ & $13.6 \pm 2.1^{1}$ & $12.3 \pm 1.7^{1}$ \\
\hline DMSO + BSA & $49.3 \pm 8.7^{1.2}$ & $26.6 \pm 2.4^{1.2}$ & $13.6 \pm 1.4^{1.2}$ & $10.4 \pm 0.9^{1.2}$ \\
\hline DMASO + FG & $52.4 \pm 7.8^{1.2}$ & $28.3 \pm 2.7^{1.2}$ & $16.5 \pm 1.9^{1.2}$ & $2.8 \pm 0.5^{1.2}$ \\
\hline GLYCEROL & $37.1 \pm 6.3^{1}$ & $35.9 \pm 5.4^{1}$ & $15.2 \pm 2.5^{1}$ & $11.8 \pm 2.2^{1}$ \\
\hline GLYCEROL + BSA & $33.1 \pm 5.3^{1.2}$ & $34.2 \pm 4.5^{1.2}$ & $19.5 \pm 1.9^{1.2}$ & $13.2 \pm 1.7^{1.2}$ \\
\hline GLYCEROL + FG & $68.8 \pm 15.7^{1.2 .3}$ & $15.9 \pm 2.1^{1.2 .3}$ & $12.7 \pm 1.6^{1.2 .3}$ & $2.7 \pm 0.4^{1.2 .3}$ \\
\hline INTACT CONTROL & $92.1 \pm 1.3$ & $6.9 \pm 1.3$ & $0.5 \pm 0.3$ & $0.6 \pm 0.4$ \\
\hline
\end{tabular}

Table 2. Status of nuclei of spermatogenic epithelium cells after cryopreservation of convoluted seminiferous tubules of prepubertal rats' testis, $\%$ of cells.

Notes: $^{1}$ - the difference is significant
compared to intact control; ${ }^{2}$ - the difference
is significant compared to the corresponding
control; $^{3}$ - the difference is significant
compared to the corresponding cryoprotectant
in combination with BSA $(p<0.05 ; n=5)$.



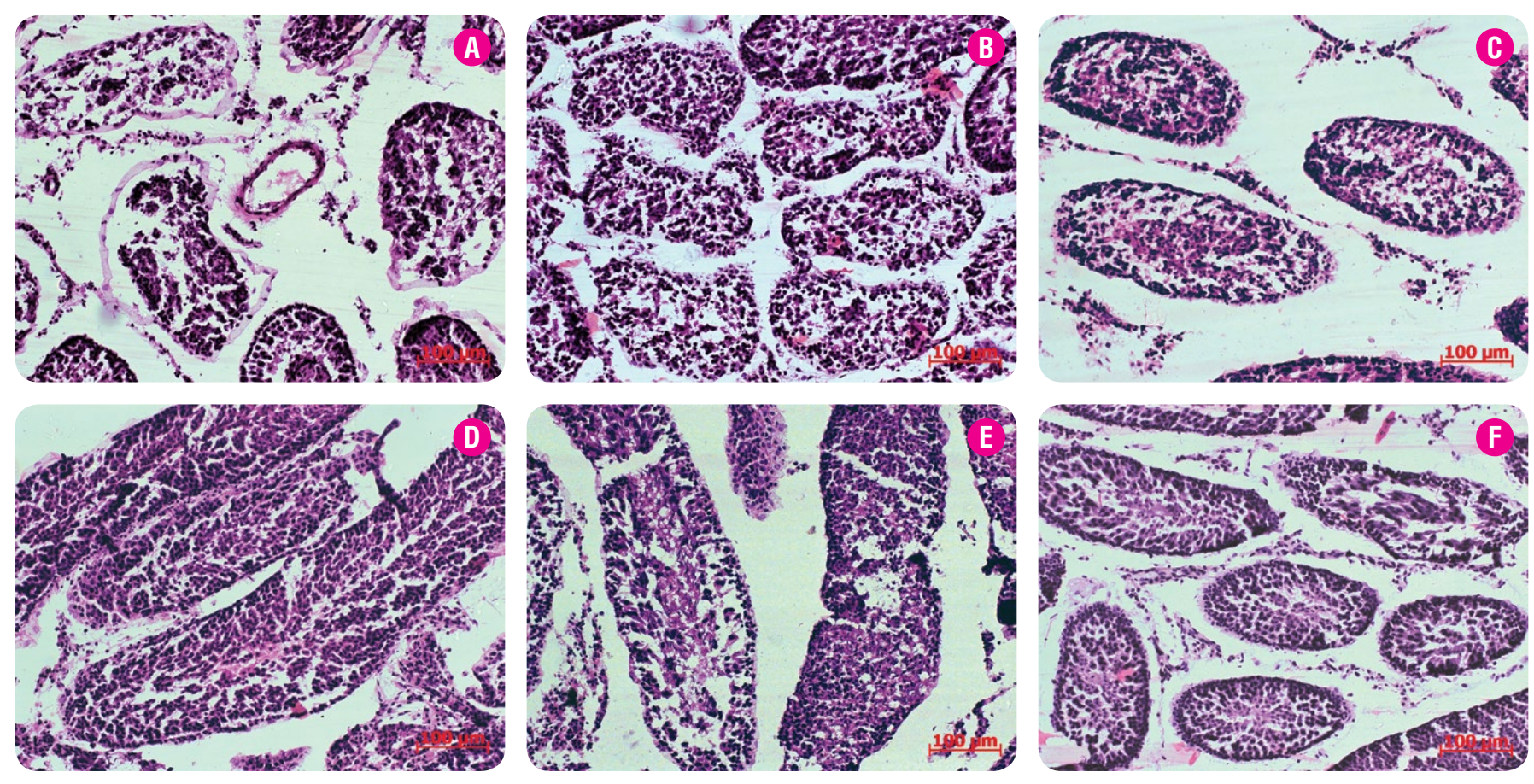

Fig. 2. Microphotography of histological sections of convoluted seminiferous tubules of prepubertal rats' testis after cryopreservation with: A - DMSO; B - glycerol; C -DMSO + BSA; D - glycerol + BSA; E-DMSO+FG; F- glycerol + FG; hematoxylin and eosin staining.

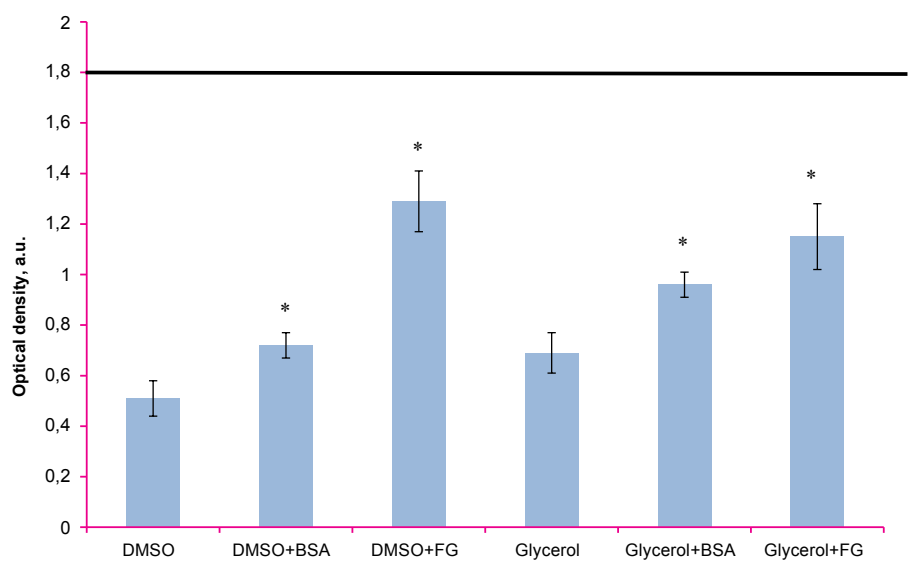

Fig. 3. Metabolic activity of cryopreserved convoluted seminiferous tubules of prepubertal rats' testis by optical density of the formazan solution in the MTT test.

Notes: solid line - indicator of intact control; DMSO - dimethyl sulfoxide, BSA - bovine serum albumin, FG - fibrin gel; * - the difference is significant compared to the corresponding cryoprotectant $(p<0.05 ; n=5)$.

was 1.4 and 1.7 times higher, respectively, relative to control (glycerol). However, the metabolic activity of cells in all investigated cryopreserved samples was significantly lower than in intact control.

Thus, the level of metabolic activity in samples of convoluted seminiferous tubules of rats' testis decreases after freezing-thawing. In addition, the present study has shown that the use of a polymer in the form of a gel helps to reduce the damage of low temperatures. The fibrin gel in combination with both DMSO and glycerol, during programmed cryopreservation, contributed to preserving of the metabolic activity of convoluted seminiferous tubules cells of immature rats' testis at a significantly higher level than with BSA and using a corresponding cryoprotectant separately.

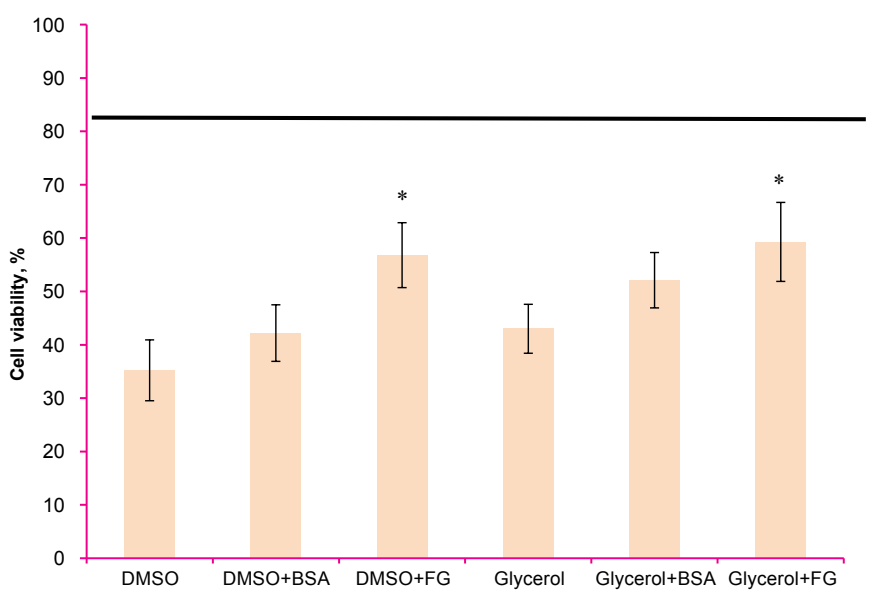

A

Fig. 4. Cell viability in convoluted seminiferous tubules of prepubertal rats' testis after cryopreservation and thawing.

Notes: solid line - indicator of intact control; DMSO - dimethyl sulfoxide, BSA - bovine serum albumin, FG - fibrin gel;

- the difference is significant compared to the corresponding cryoprotectant $(p<0.05 ; n=5)$

An assessment of the effect of programmed freezing on the viability of cells of the convoluted seminiferous tubules of rats' testis is shown in Fig. 4. In samples cryopreserved with DMSO + FG, the number of viable cells was 1.6 times higher than in the control (DMSO). The use of glycerol in combination with FG contributed to an increase in this index by 1.4 times relative to control (glycerol). In all tested samples, the number of intact cells after cryopreservation was significantly lower than intact control. In contrast to BSA, the use of FG in cryopreservation of convoluted seminiferous tubules is more effective in maintaining the cells viability in combination with both DMSO and glycerol.

Modern developments of innovative biomaterials have made a significant contribution to the development of reproductive medicine, 
especially in the fertility preservation. The analysis of the data shows that the level of metabolic activity after freezing-thawing in the samples of convoluted tubules of rats' testis decreased. It should be noted that the use of biopolymers weakened the damaging effect of low-temperature preservation.

According to the literature, additional components of media that reduce cell damage during cryopreservation are protein supplements [29]. It was shown [30] that the use of fetal bovine serum, BSA, recombinant protein in cryoprotective media enhances cell viability after freezingthawing. However, the addition of xenogeneic serum to cryoprotective media has a number of disadvantages: the variability of its composition, the possibility of contamination by viruses and the presence of undesirable biologically active substances. However, in most of the existing protocols testicular tissues cryopreservation, serum albumin is applied as a protein component $[8,16]$

Fibrin gel is a biological material that can be used in the autologous system and is a high-density fibrin network that includes a large number of biologically active compounds, the main of which are PDGF (platelet-derived growth factor), TGF (transforming growth factor), FGF (fibroblast growth factor) and IGF (insulin-like growth factor) [31]. These growth factors can affect the metabolic processes of cells and play a major role in regulating the process of reparation and regeneration. For example, insulin-like growth factor I (IGF-I) is an important regulator of reproductive function. In particular, it was reported that IGF-I stimulates mobility, viability, condensation and sperm acrosome reaction. Adding of this factor to the cryopreservation medium of sperm reduces cell apoptosis [32]. In addition, one of FG features is a high viscosity, whose intensity is inversely dependent on temperature. The viscosity of the cryopreservation medium influences on the dynamics of crystallization, providing conditions for the formation of fine crystalline ice. This enhances reducing the degree of mechanical damage to the tissue by growing ice crystals during cryopreservation [33]. Thus, the use of FG in the cryopreservation solution promotes the binding of free water and stabilization of the cell membrane in the tissue, which in its turn increases their resistance to low temperatures.

The data obtained in our work showed that cryopreservation of seminiferous tubule fragments using a slow controlled cooling rate and a mixture of fibrin gel and $0,7 \mathrm{M}$ glycerol can maintain their histological structure and metabolic activity and is more effective than the use of bovine serum albumin. These results can be taken into account when creating cryobank of human tissues with the possibility of their subsequent application for the needs of biotechnology and in clinical practice in order to preserve male fertility.

\section{CONCLUSION}

1. Cryopreservation of convoluted seminiferous tubules of prepubertal rats' testis with the use of biopolymers in programmed freezing with a controlled slow cooling rate promotes preservation of histological structure and metabolic activity of the spermatogenic epithelial cells.

2. The use of fibrin gel as the basis for the cryoprotective medium is more effective than bovine serum albumin.

3. The obtained data can be used for the substantiation and development of effective methods of cryopreservation of convoluted seminiferous tubules with the application of biopolymers to cryobanking of immature testicular tissue.

The study was carried out with the support of the program of the National Academy of Science of Ukraine «Support

for the development of priority areas of scientific research» (code 5641230), the contract number 2.2.6.99.

1. Poels J, Abou-Ghannam G, Decamps A, et al. Transplantation of testicular tissue in alginate hydrogel loaded with VEGF nanoparticles improves spermatogonial recovery. J Control Release. 2016; 234:79-89. DOl:10.1016/j.jconrel.2016.05.037.

2. Kaneko H, Kikuchi K, Men NT, et al. Embryo production by intracytoplasmic injection of sperm retrieved from Meishan neonatal testicular tissue cryopreserved and grafted into nude mice. Anim Sci J. 2018; 1-9. DOI: 10.1111/asj.13138.

3. Pukazhenthi BS, Nagashima J, Travis AJ, et al. Slow freezing, but not vitrification supports complete spermatogenesis in cryopreserved, neonatal sheep testicular xenografts. PLoS One. 2015; 10(4):e0123957. DOI: 10.1371/journal.pone.0123957.

4. Liu Z, Nie YH, Zhang CC, et al. Generation of macaques with sperm derived from juvenile monkey testicular xenografts. Cell Res. 2016; 26(1):139-142. D0I: 10.1038/cr.2015.112

5. Shinohara $T$, Inoue $K$, Ogonuki $N$, et al. Birth of offspring following transplantation of cryopreserved immature testicular pieces and in vitro microinsemination. Hum Reprod. 2002; 17(12):3039-3045.

6. Ohta $\mathrm{H}$. Wakayama $T$. Generation of normal progeny by intracytoplasmic sperm injection following grafting of testicular tissue from cloned mice that died postnatally. Biol Reprod. 2005; 73(3):390-395. DOI: 10.1095/biolreprod.105.041673.

7. Lo KC, Yildiz C, Zhu Y, et al. Human Fetal Testicular Tissue Xenotransplantation: A Platform to Study the Effect of Gonadotropins on Human Germ Cell Development In Utero. J Urol. 2015; 194(2):585-91. DOI: 10.1016/j.juro.2015.01.099.

8. Poels J, Abou-Ghannam G, Herman S, et al. In search of better spermatogonial preservation by supplementation of cryopreserved human immature testicular tissue xenografts with N-acetylcysteine and testosterone. Front Surg. 2014; 1:47. DOI: 10.3389/fsurg.2014.00047.

9. Poels J, Van Langendonckt A, Many MC, et al. Vitrification preserves proliferation capacity in human spermatogonia. Hum Reprod. 2013; 28(3):578-589. D0I: 10.1093/humrep/des455.

10. Wyns C, Van Langendonckt $A$, Wese $F X$, et al. Long-term spermatogonial survival in cryopreserved and xenografted immature human testicular tissue. Hum Reprod. 2008; 23(11):2402-2414. DOI: 10.1093/humrep/den272.

11. Dafopoulos K, Griesinger G, Schultze-Mosgau A, et al. Cumulative pregnancy rate after ICSI with cryopreserved testicular tissue in non-obstructive azoospermia. Reprod Biomed Online. 2005; 10(4):461-6.

12. Picton HM, Wyns C, Anderson RA, et al. European perspective on testicular tissue cryopreservation for fertility preservation in prepubertal and adolescent boys. Hum Reprod. 2015; 30(11):2463-75. DOI: 10.1093/humrep/dev190. 
13. Kanbar M, de Michele F, Wyns C. Cryostorage of testicular tissue and retransplantation of spermatogonial stem cells in the infertile male. Best Pract Res Clin Endocrinol Metab. 2018. pii: S1521-690X(18)30117-9. DOI: 10.1016/j.beem.2018.10.003.

14. Wyns C, Curaba M, Vanabelle B, et al. Options for fertility preservation in prepubertal boys. Hum Reprod Update. 2010; 16(3):312-328. D0I: 10.1093/humupd/ dmp054.

15. Keros V, Hultenby $K$, Borgström B, et al. Methods of cryopreservation of testicular tissue with viable spermatogonia in pre-pubertal boys undergoing gonadotoxic cancer treatment. Hum Reprod. 2007; 22(5):1384-1395. D0I: 10.1093/humrep/del508.

16. Milazzo JP, Travers A, Bironneau A, et al. Rapid screening of cryopreservation protocols for murine prepubertal testicular tissue by histology and PCNA immunostaining. J Androl. 2010; 31(6):617-630. D0I: 10.2164/jandrol.109.009324.

17. Jahnukainen K, Ehmcke J, Hergenrother SD, et al. Effect of cold storage and cryopreservation of immature non-human primate testicular tissue on spermatogonial stem cell potential in xenografts. Hum Reprod. 2007; 22(4):1060-1067. DOI: 10.1093/humrep/del471.

18. Onofre J, Baert $Y$, Faes $K$, et al. Cryopreservation of testicular tissue or testicular cell suspensions: a pivotal step in fertility preservation. Hum Reprod Update. 2016; 22(6):744-761. DOI: 10.1093/humupd/dmw029.

19. Volkova NO, Yukhta MS, Chernyshenko LS, et al. Cryopreservation of rat seminiferous tubules using biopolymers and slow non-controlled rate cooling. Probl Cryobiol Cryomed 2018; 28(4):278-292. DOI: 10.15407/cry028.04.278.

20. Miyamoto $Y$, Enosawa $S$, Takeuchi $T$, et al. Cryopreservation in situ of cell monolayers on collagen vitrigel membrane culture substrata: ready-to-use preparation of primary hepatocytes and ES cells. Cell Transplant. 2009; 18(5):619-626.

21. Volkova NO, Yukhta MS, Chernyshenko LG, et al. Exposure of seminiferous tubules of immature rats to cryoprotective media of various compositions. Probl Cryobiol Cryomed. 2017; 27(3): 203-218. DOI: 10.15407/cry027.03.203.

22. Volkova N, Yukhta M, Goltsev A. Biopolymer gels as a basis of cryoprotective medium for testicular tissue of rats. Cell and tissue banking. 2018 ; $19(4): 819-826$. DOI: 10.1007/s10561-018-9740-z.

23. Campion SN, Carvallo FR, Chapin RE, et al. Comparative assessment of the timing of sexual maturation in male Wistar Han and Sprague-Dawley rats. Reprod Toxicol. 2013; 38(7):16-24. DOI.org/10.1016/j.reprotox.2013.02.003.

24. Council of Europe [France]. European convention fort heprotection of vertebrate animals used for experimental and other scientific purposes. Strasbourg, 18.III.1986. http://conventions.coe.int/treaty/en/Treaties/Word/123.doc

25. Milazzo JP, Vaudreuil L, Cauliez B, et al. Comparison of conditions for cryopreservation of testicular tissue from immature mice. Hum Reprod. 2008; 23(1):17-28. DOI: $10.1093 /$ humrep/dem355

26. Travers A, Milazzo JP, Perdrix A, et al. Assessment of freezing procedures for rat immature testicular tissue. Theriogenology. 2011; 76(6):981-990. D0I: 10.1016/j. theriogenology.2011.04.025.

27. Mossman T. Rapid colorimetric assay for cellular growth and survival: application to proliferation and cytotoxicity assays. J Immunol Methods. 1983; 65(1-2):5563. DOl.org/10.1016/0022-1759(83)90303-4.

28. Ogawa T, Arechaga JM, Avarbock MR, Brinster RL. Transplantation of testis germinal cells into mouse seminiferous tubules. International Journal of Developmental Biology. 2003; 41(1):111-122.

29. Grill G. Porcellini A, Lucarelli G. Role of serum on cryopreservation and subsequent viability of mouse bone marrow hemopoetic stem cells. Cryobiology. 1980; 17(5):516-20

30. Dimasi L. Meeting increased demands on cell-based processes by using defined media supplements. BioProcess International. 2011; 9 (8):48-58.

31. Nishiyama K, Okudera T, Watanabe $T$, et al. Basic characteristics of plasma rich in growth factors (PRGF): blood cell components and biological effects. Clin Exp Dent Res. 2016; 2(2):96-103. D0I: 10.1002/cre2.26.

32. Makarevich AV, Spalekova E, Olexikova L, et al. Effect of insulin-like growth factor I on functional parameters of ram cooled-stored spermatozoa. Zygote. 2014; 22(3):305-313. DOl: 10.1046/j.1365-2265.1998.00517.x.

33. Takahashi T, Hirsh A, Erbe E, et al. Mechanism of cryoprotection by extracellular polymeric solutes. Biophys J. 1988; 54(3):509-18. D0I: 10.1016/S00063495(88)82983-7.

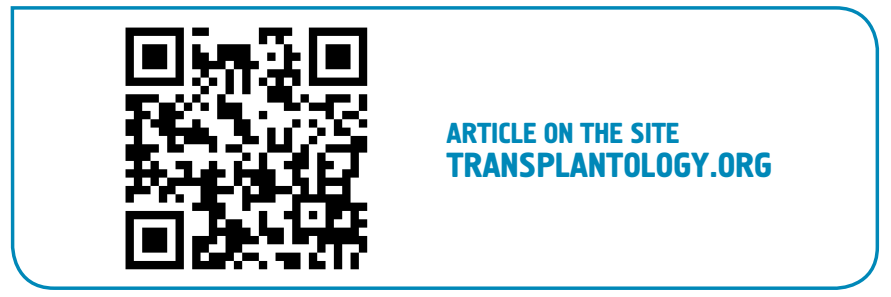

The authors indicate no potential conflicts of interest.

Received: February 06, 2019

Accepted: May 31, 2019 